\title{
Kombinasi Pijat Endorphin dan Auditori Murottal Terhadap Kualitas Nyeri Persalinan Kala I: Literature Review
}

\author{
Sintia Taubatul Fitria ${ }^{a}$, Rudiyanto ${ }^{a}$, Indah Christiana ${ }^{a}$ \\ a STIKES Banyuwangi, Indonesia \\ E-mail korespondensi: rudiyanato.roqy@gmail.com
}

\begin{abstract}
Introduction: Physiologically, the process of labor makes a laboring woman feeling pain. Severe labor pain that cannot be tolerated by the laboring woman can cause complications in the labor process. Labor pain can be overcome with non-pharmacological therapies including endorphin massage therapy and Al-Quran Murottal. The purpose of this literature review was to determine the effectiveness of combination of endorphin massage and Al Qur'an murottal auditory on stage I labor pain. Method: This study was a literature review by searching articles method using PICOT question on Google Scholar and Garuda Portal database. Searches were limited to full text articles, in Bahasa Indonesia and English, which were published in 2010-2020. Thirty four articles were found, identified and then screened. Result: Researcher found 11 articles that in accordance with the inclusion and exclusion criteria. 6 articles used endorphin massage therapy and 5 articles used Al-Quran murottal. The entire journal articles proved that endorphin massage therapy and Al-Quran murottal can affect the quality of stage I labor pain. Conclusion: Endorphin massage and Al-Quran murottal can be used as an alternative therapy for labor pain, so both of them can be collaborated to produce more effective therapy.
\end{abstract}

Keywords:, Endorphin Massage, Al-Quran Murottal, Stage I Labor Pain.

\begin{abstract}
Abstrak
Pendahuluan: Proses persalinan secara fisiologis menyebabkan ibu bersalin merasakan nyeri. Nyeri persalinan yang tinggi dan tidak dapat ditoleransi oleh ibu bersalin dapat menyebabkan komplikasi dalam persalinan. Nyeri persalinan dapat diatasi dengan terapi non farmakologi diantaranya dengan terapi pijat endorphin dan murottal Al-Quran. Tujuan literature review ini untuk mengetahui efektivitas kombinasi pijat endorphin dengan auditori murottal terhadap nyeri persalinan kala I. Metode: Study ini merupakan literature review dengan metode pencarian artikel menggunakan PICOT question pada database Google Scholar dan Portal Garuda. Penelusuran dibatasi pada artikel teks lengkap, berbahasa Indonesia dan Inggris, yang diterbitkan pada tahun 2010-2020 didapatkan 34 artikel dan selanjutnya dilakukan identifikasi dan screening. Hasil: Peneliti menemukan 11 artikel yang sesuai dengan kriteria inklusi dan eksklusi. 6 artikel menggunakan terapi pijat endorphin dan 5 artikel menggunakan murottal Al-Quran. Keseluruhan artikel jurnal tersebut membuktikan bahawa terapi pijat endorphin dan murottal Al-Quran dapat mempengaruhi kualitas nyeri persalinan kala I. Kesimpulan: Pijat endorphin maupun murottal Al-Quran dapat digunakan sebagai alternatif terapi nyeri persalinan, sehingga keduanya dapat dikolaborasikan untuk menghasilkan terapi yang lebih efektif.
\end{abstract}

Kata kunci: Pijat Endorphin, Murotal Al-Qur'an, Nyeri Persalinan Kala 1 


\section{PROFESIONAL HEALTH JOURNAL}

Volume2, No. 2, Juni 2021 (Hal. 64-74)

https://www.ojsstikesbanyuwangi.com/index.php/PHJ

\section{PENDAHULUAN}

Persalinan merupakan proses membuka dan menipisnya serviks dan turunnya Janin ke dalam jalan lahir (Manuaba, 2012). Proses tersebut menyebabkan adanya kontraksi uterus, dilatasi serviks dan peregangan segmen bawah uterus yang menyebabkan rasa nyeri (Aprilia, 2019). Nyeri persalinan merupakan keadaan fisiologis dalam persalinan yang menimbulkan rasa tidak nyaman akibat rangsangan pada ujungujung saraf tertentu (Alyensi \& Arifin, 2017).

Berdasarkan penelitian di Amerika Serikat $70 \%$ - $80 \%$ wanita yang melahirkan mengharapkan persalinan berlangsung tanpa rasa nyeri. Saat ini di Negara berkembang 20\% - 50\% persalinan di rumah sakit besar dilakukan dengan sectio caesaria disebabkan ibu bersalin lebih memilih operasi yang relative tidak merasakan nyeri (Hindriati, dkk., 2019). Mulyani (2018) menyatakan di Indonesia dari data persatuan rumah sakit di seluruh Indonesia didapatkan $15 \%$ ibu bersalin mengalami komplikasi persalinan, $21 \%$ ibu menyatakan bahwa persalinan yang dialami merupakan persalinan yang menyakitkan, sedangkan $63 \%$ ibu tidak mengetahui tentang persiapan yang harus dilakukan untuk mengurangi nyeri persalinan (Mulyani, 2018). Data RISKESDAS tahun 2018 di Jawa Timur terdapat $76,9 \%$ dari ibu bersalin melakukan persalinan dengan persalinan normal (RISKESDAS, 2018). Data ibu bersalin yang terlapor di Banyuwangi pada tahun 2017 yaitu 23.003 ibu bersalin terdapat 19.595 ibu dengan persalinan normal (Dinas Kesehatan Kabupaten Banyuwangi, 2017). Berdasarkan data yang didapatkan di BPM Ny. Nur Laila Hayati, S.KM., M.PH. Desa Gitik Kecamatan Rogojampi Kabupaten
Banyuwangi pada bulan Januari Desember tahun 2018 terdapat 486 ibu bersalin dengan rata-rata per bulan terdapat 40 ibu bersalin. Erika Prawitasari (2018) dalam penelitiannya menyatakan bahwa dari 15 ibu bersalin kala I di BPM Ny. Nur Laila Hayati, S.KM., M.PH. 7\% ibu bersalin mengalami sangat nyeri, $53 \%$ ibu bersalin mengalami nyeri berat, $40 \%$ ibu bersalin mengalami nyeri sedang.

Nyeri persalinan kala I dikarenakan kontraksi miometrium disertai regangan segmen bawah rahim, yang menyatu dengan kondisi psikologis ibu selama persalinan, yaitu kecemasan, kelelahan, dan kekhawatiran sehingga dapat memperberat nyeri fisik yang sudah ada (BD, Yefrida \& Masmura, 2017). Nyeri persalinan yang berlebihan dan terlalu lama akan menimbulkan kecemasan dan tekanan psikologis, sehingga dapat mempengaruhi keadaan fisik ibu bersalin, seperti peningkatan tekanan darah, frekuensi nafas dan denyut jantung. Apabila hal ini terus terjadi, maka nyeri yang hebat selama persalinan dapat menimbulkan kelelahan pada ibu sehingga berisiko terjadinya partus lama yang dapat membahayakan ibu dan janin. dan dapat menjadi salah satu penyebab kematian ibu dan anak (Alyensi \& Arifin, 2018). Selain itu nyeri persalinan juga dapat mempengaruhi psikologis ibu. Nyeri yang tidak tertangani akan menimbulkan rasa cemas pada ibu, dan sebaliknya rasa cemas yang berlebihan juga dapat menambah intensitas nyeri yang dirasakan ibu bersalin (Aprilia, 2019).

Penanganan nyeri persalinan dapat dilakukan dengan berbagai metode, baik secara farmakologi dan non-farmakologi (Alyensi \& Arifin, 2018). Terapi non farmakologi untuk menangani nyeri persalinan diantaranya, terapi musik, relaksasi nafas dalam, hypnobirthing, akupuntur, akupresur, water birth, massage (pijat) (Aprilia, 2019). Massage (pijat) 


\section{PROFESIONAL HEALTH JOURNAL}

Volume2, No. 2, Juni 2021 (Hal. 64-74)

https://www.ojsstikesbanyuwangi.com/index.php/PHJ

yang dapat diberikan kepada ibu hamil salah satunya dengan pijat endorphin (Irawati, 2018). Pelaksanaan terapi pijat endorphin diperlukan sesuatu yang dapat menentramkan psikologis ibu bersalin, seperti mengucapkan kata-kata halus dan lembut atau kata-kata cinta dan lain sebagainya (Aprilia, 2019). Penanganan nyeri persalinan juga dapat dilakukan dengan terapi murottal Al-Quran (Trianingsih, 2019). Terapi murottal AlQuran dipercaya dapat menenangkan fisik dan psikis melalui aspek spiritual sehingga dapat menurunkan intensitas nyeri persalinan (Diana, 2016).

Melihat pentingnya penanganan nyeri persalinan I, maka perlu diberikan inovasi dalam penanganan nyeri persalinan kala I yaitu dengan mengkombinasikan pijat endorphin dengan auditori murottal, sehingga diperlukan telaah artikel mengenai pengguanaan pijat endorphin dan murottal Al-Quran terhadap nyeri persalinan kala I. Adapun murottal yang digunakan antara lain Q.S. Ar-Rahman, Q.S. Al-Insan, Q.S. Al-Mulk, Q.S. Maryam, Q.S. Al-Kahfi, Q.S. Al-Fatihah, Q.S. Al-Ikhlas, Q.S. Al-Falaq, Q.S. AnNaas.

\section{METODE}

Pencarian artikel menggunakan framework PICOT question, dilakukan pada database Google Scholar dan Portal Garuda dengan menggunakan kata kunci "Nyeri Persalinan Kala I", "Pijat Endorphin". "Murottal Al-Quran", "Pijat Endorphin terhadap Nyeri Persalinan Kala I", dan "Murottal Al-Quran terhadap Nyeri Persalinan Kala I". Didapatkan total keseluruhan 34 artikel. Dari jumlah artikel ada 20 artikel yang memiliki kriteria penuh, 10 artikel yang berkualitas menengah, dan 4 artikel yang berkualitas rendah. Penelitian ini dilakukan mulai tanggal 23 April - 23 Mei 2020. Populasi yaitu 192 artikel atau jurnal tentang "pijat endorphin dan murotal al-qur'an". Sampel ialah 11 artikel atau jurnal tentang Isu kombinasi pijat endorphin dan murotal alqur'an menurunkan intensitas nyeri persalinan kala 1. Jenis data yang digunakan penulis dalam penelitian ini adalah data sekunder yaitu data yang diperoleh dari jurnal, buku, dokumentasi, melalui EBSCO dan Science Direct.

Kriteria inklusi yang digunakan peneliti yaitu artikel penelitian eksperimental. Perlakuan yang digunakan dalam artikel yaitu terapi pijat endorphin, murottal Al-Quran. Artikel yang menggunakan responden ibu bersalin kala I. Hasil penelitian yang dipublikasikan dalam rentang tahun 2010-2020. Jurnal berbahasa Indonesia dan bahasa Inggris.

\section{HASIL DAN PEMBAHASAN}

Setelah dilakukan pencarian artikel sesuai dengan batasan karakteristik terdapat 11 artikel yang terpilih (6 artikel mengenai pijat endorphin dan 5 artikel mengenai murottal Al-Quran). Artikel yang terpilih menunjukkan bahwa pijat endorphin dan murottal Al-Quran dapat menurunkan nyeri persalinan kala I. 


\section{PROFESIONAL HEALTH JOURNAL}

Volume2, No. 2, Juni 2021 (Hal. 64-74)

https://www.ojsstikesbanyuwangi.com/index.php/PHJ

Tabel 1

\begin{tabular}{|c|c|c|c|c|}
\hline No & Judul & Metode & Hasil & Kesimpulan \\
\hline 1 & $\begin{array}{lr}\text { Pengaruh } & \\
\text { Endorphin } & \\
\text { Masssage } & \\
\text { terhadap } & \\
\text { Intensitas } & \text { Nyeri } \\
\text { pada } & \text { Ibu } \\
\text { Bersalin } & \\
\text { (Khasanah } & \text { \& } \\
\text { Sulistyawati, } & \\
\text { 2020) } & \end{array}$ & $\begin{array}{l}\text { Pra } \\
\text { eksperimental } \\
\text { pre - post } \\
\text { test design. }\end{array}$ & $\begin{array}{l}\text { Sebelum diberikan intervensi terdapat } 18 \\
\text { orang }(41,6 \%) \text { mengalami nyeri sangat berat, } \\
\text { setelah dilakukan intervensi terdapat } 7 \text { orang } \\
(50 \%) \text { mengalami nyeri sedang. Rerata } \\
\text { sebelum dilakukan intervensi } 8,375 \text { dan } \\
\text { sesudah dilakukan intervensi sebesar } 5,16 \\
\text { sehingga rerata skor akhir } 3,16 \text {. Setelah } \\
\text { dilakukan uji analisis t-test didapatkan nilai } \\
\text { (p=0,00) hal ini menunjukan bahwa } \\
\text { endorphin massage memiliki efek terhadap } \\
\text { penurunan intensitas nyeri yang bermakna } \\
\text { pada ibu bersalin kala I fase aktif. }\end{array}$ & $\begin{array}{l}\text { Pijat endorphin } \\
\text { dapat menurunkan } \\
\text { intensitas nyeri } \\
\text { yang signifikan } \\
\text { pada ibu bersalin } \\
\text { kala I fase aktif }\end{array}$ \\
\hline 2 & $\begin{array}{l}\text { Efektifitas } \\
\text { Endorphin } \\
\text { Massage } \\
\text { terhadap } \\
\text { Intensitas Nyeri } \\
\text { Persalinan } \\
\text { pada Iala I } \\
\text { Bersalin Ibu } \\
\text { (Tanjung \& } \\
\text { Antoni, 2019) }\end{array}$ & $\begin{array}{l}\text { Quasi } \\
\text { eksperimental } \\
\text { dengan one } \\
\text { group pre- } \\
\text { post test only. }\end{array}$ & $\begin{array}{l}\text { Rata-rata nyeri persalinan kala I sebelum } \\
\text { dilakukan intervensi sebesar } 6,38 \text { dan setelah } \\
\text { dilakukan intervensi sebesar 5,19. Setelah } \\
\text { dilakukan uji T didapatkan hasil nilai } p \text {-value } \\
0,001 \text { dengan } \alpha=0,05 \text { artinya terdapatt } \\
\text { perbedaan intensitas nyeri persalinan kala I } \\
\text { pada ibu bersalin. }\end{array}$ & $\begin{array}{l}\text { Pijat endorphin } \\
\text { efektif untuk } \\
\text { menurunkan } \\
\text { intensitas nyeri } \\
\text { persalinan kala I } \\
\text { pada ibu bersalin. }\end{array}$ \\
\hline 3 & $\begin{array}{l}\text { Terapi } \\
\text { Endorphin } \\
\text { Massage untuk } \\
\text { Menurunkan } \\
\text { Intensitas Nyeri } \\
\text { Kala I Fase Aktif } \\
\text { Persalinan (W } \\
\text { Leny \& } \\
\text { Machfudloh, } \\
\text { 2017) }\end{array}$ & $\begin{array}{l}\text { Quasi } \\
\text { eksperimental } \\
\text { with pre-post } \\
\text { test design. }\end{array}$ & $\begin{array}{l}\text { Sebelum dilakukan intervensi sebagian besar } \\
\text { responden mengalami nyeri berat yaitu } 13 \\
\text { responden }(65 \%), 1 \text { responden mengalami } \\
\text { nyeri sedang }(5 \%) \text {, dan } 6 \text { responden } \\
\text { mengalami sangat nyeri }(30 \%) \text {. Setelah } \\
\text { dilakukan intervensi } 14 \text { resonden mengalami } \\
\text { penurunan menjadi nyeri sedang }(70 \%), 3 \\
\text { respoden mengalami penurunan dari skala } \\
\text { sangat berat ke nyeri berat (15\%), } 3 \\
\text { responden tidak mengalami penurunan skala } \\
\text { nyeri (nyeri berat) (15\%). Setelah dilakukan } \\
\text { uji analisis Spearmen Rank didaptkan p-value } \\
0,004 \text { dengan } \alpha=0,05 \text { artinya ada pengaruh } \\
\text { pemberian endorphin massage terhadap nyeri } \\
\text { persalinan kala I. }\end{array}$ & $\begin{array}{l}\text { Adanya pengaruh } \\
\text { pijat endorphin } \\
\text { terhadap nyeri } \\
\text { persalinan kala I }\end{array}$ \\
\hline 4 & $\begin{array}{l}\text { Pengaruh } \\
\text { Endorphin } \\
\text { Masssage } \\
\text { terhadap Skala } \\
\text { Inensitas Nyeri } \\
\text { Kala I Fase Aktif } \\
\text { Persalinan } \\
\text { (Antik, Lusiana, } \\
\text { \& Handayani, } \\
\text { 2017) }\end{array}$ & $\begin{array}{l}\text { Quasi } \\
\text { eksperimental } \\
\text { one group } \\
\text { pre-post test } \\
\text { design. }\end{array}$ & $\begin{array}{l}\text { Terdapat } 13 \text { responden yang mengalami } \\
\text { nyeri berat sebelum dilakukan intervensi, } \\
\text { sesudah dilakukan intervensi tidak ditemukan } \\
\text { kembali responden yang mengalami nyeri } \\
\text { berat. Terdapat perubahan skala nyeri } \\
\text { sesudah diberikan intervensi, yaitu pada nyeri } \\
\text { ringan didapatkan kenaikan dari yang hanya } \\
1 \text { responden }(3,33 \%) \text { menjadi } 11 \text { responden } \\
\text { (36,7\%), pada nyeri berat terdapat } 13 \\
\text { responden (43,33\%) menjadi } 6 \text { responden } \\
(20 \%) \text {, sedangkan pada kriteria nyeri sangat } \\
\text { berat tidak ditemukan lagi setelah dilakukan } \\
\text { intervensi. Setelah dilakukan uji analisis } \\
\text { wilcoxon didapatkan positive rank sebanyak } \\
23 \text { orang, artinya ada } 23 \text { responden } \\
\text { menunjukkan respon yang lebih baik } \\
\text { terhadap skala nyeri persalinan kala I setelah }\end{array}$ & $\begin{array}{l}\text { Adanya pengaruh } \\
\text { yang signifikan } \\
\text { pemberian pijat } \\
\text { endorphin } \\
\text { terhadap intensitas } \\
\text { nyeri persalinan } \\
\text { kala I fase aktif. }\end{array}$ \\
\hline
\end{tabular}




\section{PROFESIONAL HEALTH JOURNAL}

Volume2, No. 2, Juni 2021 (Hal. 64-74)

https://www.ojsstikesbanyuwangi.com/index.php/PHJ

\begin{tabular}{|c|c|c|c|c|}
\hline & & & $\begin{array}{l}\text { diberikan pijat endorphin, dan nilai } p \text {-value } \\
\text { sebesar } 0,000 \text { dengan } \alpha=0,005 \text { artinya ada } \\
\text { pengaruh uang signifikan endorphin massage } \\
\text { terhadap skala intensitas nyeri persalinan } \\
\text { kala I fase aktif persalinan. }\end{array}$ & \\
\hline 5 & $\begin{array}{l}\text { Effectiveness of } \\
\text { Endorphin and } \\
\text { Ice Pack to } \\
\text { Relieve the First } \\
\text { Stage of Labor } \\
\text { Pain Among the } \\
\text { Pregnant Women } \\
\text { in Candimulyo } \\
\text { Health Center, } \\
\text { Indonesia. } \\
\text { (Dewi, Sukini, } \\
\text { Ath Thaariq, \& } \\
\text { Hidayati, 2018) }\end{array}$ & $\begin{array}{l}\text { Quasi } \\
\text { experiment } \\
\text { with control } \\
\text { group and } \\
\text { pre-post test } \\
\text { design. }\end{array}$ & $\begin{array}{l}\text { Hasil uji analisis wilcoxon pada kelompok } \\
\text { endorphin massage didapatkan hasil rerata } \\
\text { nyeri persalinan sebelum dilakukan } \\
\text { intervensi } 4,0000 \text {, rerata seesudah dilakukan } \\
\text { intervensi } 2,8000 \text {, dan p=0,008 artinya ada } \\
\text { pengaruh yang signifikan pemberian } \\
\text { endorphin massage terhadap nyeri persalinan } \\
\text { kala I. Sedangkan pada kelompok kompres } \\
\text { dingin didapatkan hasil rerata nyeri } \\
\text { persalinan sebelum dilakukan intervensi } \\
3,9333 \text {, rerata nyeri persalinan sesudah } \\
\text { dilakukan intervensi } 3,4667 \text { dan p=0,000 } \\
\text { artinya ada pengaruh yang signifikan } \\
\text { pemberian kompres dingin terhadap nyeri } \\
\text { persalinan kala I. Setelah dilakukan uji } \\
\text { analisis Mann-Whitney didapatkan } \\
\text { perbandingan antara kelompok endorphin } \\
\text { massage dan kompres dingin yaitu } 18,50 \text { : } \\
\text { 12,50 dengan p=0,029 artinya ada perbedaan } \\
\text { yang signifikan antara endorphin massage } \\
\text { dengan kompres dingin terhadap nyeri } \\
\text { persalinan kala I, pengguanaan endorphin } \\
\text { massage lebih efektif dari pada kompres } \\
\text { dingin. }\end{array}$ & $\begin{array}{l}\text { Terdapat } \\
\text { penurunan skala } \\
\text { nyeri sebelum dan } \\
\text { sesudah dilakukan } \\
\text { pijat endorphin, } \\
\text { dan setelah } \\
\text { dilakukan uji } \\
\text { perbandingan } \\
\text { dengan kelompok } \\
\text { kompres dingin } \\
\text { didapatkan bahwa } \\
\text { pijat endorphin } \\
\text { lebih efektif dalam } \\
\text { menurunkan skala } \\
\text { nyeri pada ibu } \\
\text { bersalin kala I. }\end{array}$ \\
\hline 6 & $\begin{array}{l}\text { The Effect of } \\
\text { Endorphin } \\
\text { Massage } \\
\text { Technique } \\
\text { Toward the } \\
\text { Decrease of Pain } \\
\text { at the First } \\
\text { Childbirth in } \\
\text { BPM and } \\
\text { Society Health } \\
\text { Center } \\
\text { Palembang } \\
\text { (Azelea, Vasra, } \\
\text { \& Kadir, 2019) }\end{array}$ & $\begin{array}{l}\text { Quasi } \\
\text { eksperimental } \\
\text { with pre-post } \\
\text { test design. }\end{array}$ & $\begin{array}{l}\text { Sebelum dilakukan intervensi terdapat } 12 \\
\text { responden mengalami nyeri sedang }(60 \%) \\
\text { dan } 8 \text { responden mengalami nyeri ringan } \\
(40 \%) \text {. Setelah dilakukan intervensi terdapat } \\
1 \text { responden mengalami nyeri sedang }(5 \%) \\
\text { dan } 19 \text { responden mengalami nyeri ringan } \\
(95 \%) \text {. Setelah dilakukan uji analisis t-test } \\
\text { didapatkan hasil p-value } 0,000 \text { dengan } \\
\alpha=0,05 \text { artinya terdapat pengaruh yang } \\
\text { signifikan pemberian endorphin massage } \\
\text { terhadap nyeri persalinan kala I. }\end{array}$ & $\begin{array}{l}\text { Terdapat } \\
\text { perbedaan } \\
\text { signifikan } \\
\text { intensitas } \\
\text { persalinan } \\
\text { sebelum nyeri } \\
\text { sesudah diberikan } \\
\text { intervensi pijat } \\
\text { endorphin. }\end{array}$ \\
\hline 7 & $\begin{array}{lr}\text { Pengaruh } & \text { Terapi } \\
\text { Murottal } & \text { Al- } \\
\text { Qur'an terhadap } \\
\text { Penurunan } \\
\text { Intensitas } & \text { Nyeri } \\
\text { Ibu } & \text { Bersalin } \\
\text { Kala I Fase Aktif } \\
\text { di } r \text { Ruang } \\
\text { Bersalin } & \text { Rumah } \\
\text { Sakit } & \text { Umum } \\
\text { Daerah } & \text { Solok } \\
\text { Selatan } & \text { BD, } \\
\text { Yefrida, } & \&\end{array}$ & $\begin{array}{l}\text { Pra } \\
\text { eksperimental } \\
\text { one group } \\
\text { pre and post } \\
\text { test design. }\end{array}$ & $\begin{array}{l}\text { Rata-rata nyeri persalinan sebelum dilakukan } \\
\text { intervensi sebesar } 6,75 \text { dan rata-rata nyeri } \\
\text { persalinan sesudah diberikan intervensi } \\
\text { sebesar } 4,80 \text {. Setelah dilakukan uji t-test } \\
\text { didapatkan terdapat penurunan rata-rata nyeri } \\
\text { persalinan sebelum dilakukan intervensi } \\
\text { dengan sesudah dilakukan intervensi sebesar } \\
1,95 \text { dengan } p \text {-value sebesar } 0,0000(\alpha=0,05) \\
\text { artinya terdapat perbedaan yang signifikan } \\
\text { antara rata-rata intensitas nyeri sebelum } \\
\text { dilakukan intervensi dengan sesudah } \\
\text { dilakukan intervensi (terdapat pengaruh yang } \\
\text { signifikan pemberian murottal Al-Quran }\end{array}$ & $\begin{array}{lr}\text { Ada pengaruh } \\
\text { pemberian terapi } \\
\text { murottal Al-Quran } \\
\text { terhadap nyeri } \\
\text { persalinan kala I } \\
\text { fase aktif. }\end{array}$ \\
\hline
\end{tabular}




\section{PROFESIONAL HEALTH JOURNAL}

Volume2, No. 2, Juni 2021 (Hal. 64-74)

https://www.ojsstikesbanyuwangi.com/index.php/PHJ

\begin{tabular}{|c|c|c|c|c|}
\hline & Masmura, 2017) & & terhadap intensitas nyeri persalinan kala I). & \\
\hline 8 & $\begin{array}{lr}\text { Decrease } & \text { of } \\
\text { Anxiety and Pain } \\
\text { Delivery } & \text { of } \\
\text { Mother Inpartu } \\
\text { Primipara } & \text { on } \\
\text { First } & \text { Phase } \\
\text { Active by Giving } \\
\text { of Murottal Al } \\
\text { Quran Arrahman } \\
\text { in Midwifery } \\
\text { Pivate Clinic } \\
\text { Endang } \\
\text { Sumaningdyah } \\
\text { City of Kediri. } \\
\text { (Melda r \& } \\
\text { Mufidah, 2018) }\end{array}$ & \begin{tabular}{l} 
Pre- \\
\multicolumn{3}{l}{ experimental } \\
with $\quad$ one \\
group pre- \\
post $\quad$ test \\
design.
\end{tabular} & $\begin{array}{l}\text { Rata-rata tingkat kecemasan responden } \\
\text { sebelum dilakukan intervensi sebesar } 16,75 \\
\text { dan sesudah dilakukan intervensi } 11,25 \text {. } \\
\text { Rata-rata tingkat nyeri yang diarasakan } \\
\text { responden sebelum intervensi } 7,33 \text { dan } \\
\text { sesudah dilakukan intervensi } 6,00 \text {. Setelah } \\
\text { dilakukan uji t-test didapatakan terdapat } \\
\text { pengaruh yang signifikan pemberian terapi } \\
\text { murottal Al Quran sura Arrahman terhadap } \\
\text { tingkar kecemasan pada ibu primipara } \\
\text { (p=0,000) dan tingkat nyeri ibu primipara } \\
(0,002) \text { dengan } \alpha=0,005 \text {. }\end{array}$ & $\begin{array}{l}\text { Ada pengaruh } \\
\text { pemberian } \\
\text { murottal Al-Quran } \\
\text { surat Ar-rahman } \\
\text { terhadap nyeri } \\
\text { persalinan kala I }\end{array}$ \\
\hline 9 & $\begin{array}{l}\text { Efektivitas } \\
\text { Terapi Murottal } \\
\text { Al-Quran } \\
\text { terhadap } \\
\text { Intensitas Nyeri } \\
\text { Persalinan Kala I } \\
\text { Fase Aktif } \\
\text { (Yana, Utami, \& } \\
\text { safri, 2015) }\end{array}$ & $\begin{array}{l}\text { Quasi } \\
\text { experiment } \\
\text { with non } \\
\text { equivalent } \\
\text { control group } \\
\text { design. }\end{array}$ & 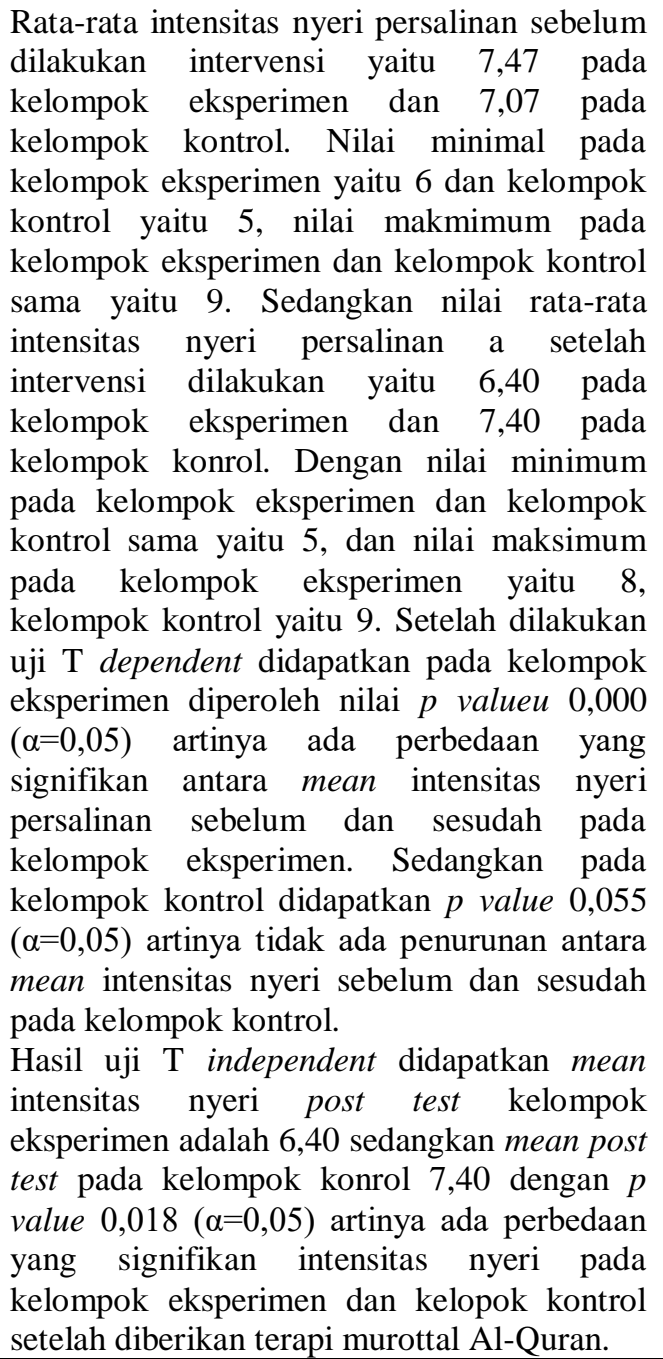 & $\begin{array}{l}\text { Terdapat pengaruh } \\
\text { yang signifikan } \\
\text { pemberian } \\
\text { murottal Al-Quran } \\
\text { terhadap kualitas } \\
\text { nyeri persalinan } \\
\text { kala I, dan setelah } \\
\text { dilakukan } \\
\text { banding dengan } \\
\text { kelompok control } \\
\text { didapatkan adanya } \\
\text { perbedaan } \\
\text { intensitas nyeri } \\
\text { persalinan kala I } \\
\text { antara kelompok } \\
\text { eksperimen } \\
\text { dengan kelompok } \\
\text { kontrol setelah } \\
\text { diberikan murottal } \\
\text { Al-Quran. }\end{array}$ \\
\hline 1 & $\begin{array}{l}\text { The } \\
\text { Effectiveness of } \\
\text { Al Qur'an } \\
\text { Healing with } \\
\text { Audio-Visual }\end{array}$ & \begin{tabular}{lr}
\multicolumn{3}{l}{ Pra } & \\
eksperimental \\
with $\quad$ one \\
group pre- \\
post $\quad$ test \\
\end{tabular} & $\begin{array}{l}\text { Rata-rata nyeri pada ibu bersalin sebelum } \\
\text { dilakukan intervensi } 7,50 \text { dengan skala nyeri } \\
\text { minimal } 4 \text { dan maksimal } 10 .\end{array}$ & $\begin{array}{l}\text { Ada pengaruh } \\
\text { pemberian } \\
\text { murottal Al-Quran } \\
\text { dengan metode } \\
\text { audio-visual }\end{array}$ \\
\hline
\end{tabular}




\section{PROFESIONAL HEALTH JOURNAL}

Volume2, No. 2, Juni 2021 (Hal. 64-74)

https://www.ojsstikesbanyuwangi.com/index.php/PHJ

\begin{tabular}{|c|c|c|c|c|}
\hline & $\begin{array}{l}\text { Methods in } \\
\text { Reducing Pain in } \\
\text { the Active Phase } \\
\text { of the First Stage } \\
\text { of Labor } \\
\text { (Salmiyati \& } \\
\text { Amizuar, 2020) }\end{array}$ & design. & $\begin{array}{l}\text { dengan skala nyeri minimal } 3 \text { dan maksimal } \\
\text { 9. Setelah dilakukan uji analisis wilcoxon } \\
\text { didapatkan p-value } 0,035 \text { dengan } \alpha=0,05 \\
\text { artinya ada pengaruh pemberian murottal } \\
\text { dengan metode audio-visual terhadap tingkat } \\
\text { nyeri persalinan kala I fase aktif. }\end{array}$ & $\begin{array}{l}\text { terhadap intensitas } \\
\text { nyeri persalinan } \\
\text { kala I. }\end{array}$ \\
\hline 11 & $\begin{array}{lr}\text { Pengaruh } & \text { Terapi } \\
\text { Murottal } & \text { Quran } \\
\text { terhadap } & \\
\text { Intensitas } & \text { Nyeri } \\
\text { Persalinan } & \text { Kala I } \\
\text { Fase Aktif di } \\
\text { Bidan } & \text { Praktik } \\
\text { Mandiri } & \text { (BPM) } \\
\text { Ernita } & \text { Kota } \\
\text { Pekanbaru } & \\
\text { Tahun } & 2017 \\
\text { (Alyensi } & \& \\
\text { Arifin, 2017) }\end{array}$ & $\begin{array}{l}\text { Quasi } \\
\text { eksperimental } \\
\text { with pre-post } \\
\text { test design. }\end{array}$ & $\begin{array}{l}\text { Rata-rata nyeri persalinan sebelum dilakukan } \\
\text { intervensi sebesar } 6,75 \text { dan rata-rata nyeri } \\
\text { persalinan sesudah diberikan intervensi } \\
\text { sebesar } 4,80 \text {. Setelah dilakukan uji t-test } \\
\text { didapatkan terdapat penurunan rata-rata nyeri } \\
\text { persalinan sebelum dilakukan intervensi } \\
\text { dengan sesudah dilakukan intervensi sebesar } \\
1,95 \text { dengan } p \text {-value sebesar } 0,0000(\alpha=0,05) \\
\text { artinya terdapat perbedaan yang signifikan } \\
\text { antara rata-rata intensitas nyeri sebelum } \\
\text { dilakukan intervensi dengan sesudah } \\
\text { dilakukan intervensi (terdapat pengaruh yang } \\
\text { signifikan pemberian murottal Al-Quran } \\
\text { terhadap intensitas nyeri persalinan kala I). }\end{array}$ & $\begin{array}{l}\text { Ada pengaruh } \\
\text { yang signifikan } \\
\text { pemberian } \\
\text { murottal Al-Quran } \\
\text { terhadap intensitas } \\
\text { nyeri persalinan } \\
\text { kala I fase aktif. }\end{array}$ \\
\hline
\end{tabular}




\section{PROFESIONAL HEALTH JOURNAL}

Volume2, No. 2, Juni 2021 (Hal. 64-74)

https://www.ojsstikesbanyuwangi.com/index.php/PHJ

Pada proses persalinan kala I terjadi kontraksi uterus dan pembukaan serviks sehingga ibu bersalin mulai merasakan nyeri. Selama proses tersebut ibu bersalin kala I yang diberikan terapi pijat endorphin secara fisiologis tubuh ibu akan merangsang pengeluaran analgesic endogen (endorphin), sehingga dapat menghambat transmisi nyeri dengan cara meningkatkan sirkulasi neurotransmitter yang dihasilkan secara alami oleh tubuh pada sinaps neural dijalur sistem saraf pusat. Endorphin berkaitan dengan membran parasimpatik, menghambat pelepasan substansi $\mathrm{P}$ yang dapat menghambat transmisi nyeri, sehingga nyeri berkurang. Ketika sentuhan dan nyeri dirangsang seccara bersamaan, sensasi sentuhan berjalan ke otak sementara sistem kontrol desenden merangsang thalamus untuk mensekresi endorphin yang menutup pintu gerbang hantaran nyeri di medulla spinalis dan mempengaruhi sitem saraf simpatis, sehingga menyebabkan sitem saraf simpatis mengalami penurunan. Penurunan sistem saraf simpatis dapat mempengaruhi penurunan ketegangan otot, penurunan kecemasan, dan penurunan nyeri (Wahyuni, Purba, \& Batubara, 2019).

Ibu bersalin yang mendapatkan terapi murottal Al-Quran mengalami ketenangan dan penurunan kualitas nyeri persalinan kala I yang dirasakan. Hal tersebut dikarenakan suara bacaan Al-Quran yang diterima oleh daun telinga akan disalurkan ke lubang telinga dan mengenai membran timpani, sehingga membuat bergetar. Getaran tersebut akan diteruskan ke tulangtulang pendengaran yang bertautan satu dengan yang lainnya. Getaran suara tersebut akan disalurkan ke saraf N VII (vestibule cokhlearis) menuju ke otak tepatnya dibagian pendengaran. Dari bagian ini sinyal bacaan Al-Quran diteruskan ke bagian postero temporalis lobus temporalis otak yang dikenal dengan area wemicke (Rochmawati, 2018).
Kemudian otak akan memproduksi zat kimia yang disebut dengan zat neuropeoptide. Molekul ini akan menyangkut kedalam reseptor-reseptor dan memberikan umpan balik berupa kenikmatan dan kenyamanan (Febriani, 2019).

Murottal Al-Quran juga mampu memacu sistem saraf parasimpatis yang mempunyai efek berlawanan dengan sistem saraf simpatis, sehingga terjadi keseimbangan pada kedua sistem saraf outonom tersebut. Hal ini yang menjadi prinsip dasar dari timbulnya respon relaksasi, yakni terjadi keseimbangan antara sistem saraf simpatis dan para simpatis (Febriani, 2019). Kondisi yang rileks dapat menurunkan rasa nyeri pada ibu bersalin (Aprilia, 2019).

Pernyataan diatas menunjukkan bahwasannya pijat endorphin maupun murottal Al-Quran dapat diberikan kepada ibu bersalin kala I sebagai alternatif terapi non farmakologi untuk mengurangi kualitas nyeri persalinan kala I dengan efek samping yang sangat minimal. Pijat endorphin dan murottal Al-Quran samasama memberikan efek penurunan terhadap kualitas nyeri pada ibu bersalin, hanya saja dari kedua terapi ini mempunyai mekanisme yang berbeda. Sehingga apabila kedua terapi ini digabungkan menimbulkan efek penurunan nyeri persalinan kala I lebih efektif, dikarenakan selain tubuh mendapatkan sensasi rileks yang dihasilkan dari sentuhan pijat endorpin, getaran suara dari murottal Al-Quran mampu membuat hati ibu bersalin menjadi tenang. Ketika fisik dan psikologis ibu bersalin mampu terjamah oleh intervensi yang diberikan 
PROFESIONAL HEALTH JOURNAL

Volume2, No. 2, Juni 2021 (Hal. 64-74)

https://www.ojsstikesbanyuwangi.com/index.php/PHJ

maka akan mempermudah dalam mengatasi nyeri persalinan.

Kombinasi dari pijat endorphin dan murottal Al-Quran dapat merangsang hipotalamus untuk mengeluarkan hormon endorphin. Hormon endorphin dapat menutup gerbang hantaran nyeri di medulla spinalis dan mempengaruhi sistem saraf simpatis dan parasimpatis, sehingga dapat menyeimbangkan kedua sistem saraf tersebut. Hal itu dapat menyebabkan penurunan ketegangan otot, penurunan kecemasan dan penurunan nyeri pada ibu bersalin. Terapi kombinasi pijat endorphin dengan murottal AlQuran dapat diberikan sesuai dengan kebutuhan ibu bersalin.

\section{KESIMPULAN DAN SARAN}

Pijat endorphin dan murottal AlQuran dapat digunakan sebagai alternatif pengobatan untuk menurunkan nyeri persalinan kala I. Perlu dilakukan penelitian secara langsung untuk mengetahui efektivitas kombinasi pijat endorphin dengan murottal Al-Quran, sehingga terapi kombinasi pijat endorphin dan murottal Al-Quran dapat diimplementasikan pada pelayanan kesehatan.

\section{UCAPAN TERIMA KASIH}

Ucapan terima kasih yang sebesarbesarnya disampaikan kepada pihak-pihak yang membantu pelaksanaan penelitian ini, yang Terhormat Ketua Program Studi S1 Keperawatan STIKES Banyuwangi yang telah mendukung dan memberikan izin dan kesempatan dalam pelaksanaan penelitian ini. Para Donatur yang telah mendukung dalam penelitian ini.

\section{DAFTAR PUSTAKA}

Alyensi, F., \& Arifin, H. (2017). Pengaruh Terapi Murottal Qur'an Terhadap Intensitas Nyeri Persalinan Kala I Fase Aktif Di Bidan Praktik Mandiri (Bpm) Ernita Kota Pekanbaru Tahun 2017. Jurnal Kebidanan, 8(1), 31-39. Retrieved from https://www.google.com/url?sa=t\&rct $=\mathrm{j} \& \mathrm{q}=\&$ esrc $=\mathrm{s} \&$ source $=$ web $\& \mathrm{~cd}=3 \&$ $\mathrm{cad}=\mathrm{rja} \& u a c t=8 \& \mathrm{ved}=2 \mathrm{ahUKEwi} 4 \mathrm{r}$ eTp_3lAhUSxTgGHVMSAC0QFjAC egQIBBAC\&url=http $\% 3 \mathrm{~A} \% 2 \mathrm{~F} \% 2 \mathrm{Fej}$ ournal.poltekkes-

smg.ac.id\%2Fojs\%2Findex.php\%2Fju rkeb\%2Farticle \%2Fdownload\%2F372 9\%2F911\&usg=AOvVaw3YTCJVEY $\mathrm{U}$

Antik, Lusiana, A., \& Handayani, E. (2017). Pengaruh Endorphine Massage Terhadap Skala Intensitas Nyeri Kala I Fase Aktif Persalinan. Jurnal Kebidanan, 6(12), 1. https://doi.org/10.31983/jkb.v6i12.19 07

Aprilia, Y. (2019). GENTLE BIRTH Cara Lembut dan Nyaman Sambut Buah Hati. Jakarta: PT Gramedia Widiasarana Indonesia.

Azelea, A., Vasra, E., \& Kadir, A. (2019). The Effect of Endorphin Message 


\section{PROFESIONAL HEALTH JOURNAL}

Volume2, No. 2, Juni 2021 (Hal. 64-74)

https://www.ojsstikesbanyuwangi.com/index.php/PHJ

Technique Towards the Decrease of Pain at the First Childbirth in BPM and Society Health Center Palembang. KnE Life Sciences, 4(10), 79.

https://doi.org/10.18502/kls.v4i10.383 1

BD, F., Yefrida, Y., \& Masmura, S. (2017). Pengaruh Terapi Murottal AlQur'an Terhadap Penurunan Intensitas Nyeri Ibu Bersalin Kala I Fase Aktif Di Ruang Bersalin Rumah Sakit Umum Daerah Solok Selatan 2017. Jik- Jurnal Ilmu Kesehatan, 1(1), 63-69. https://doi.org/10.33757/jik.v1i1.30

Dewi, M. M., Sukini, T., Ath Thaariq, N. A., \& Hidayati, N. W. (2018). Effectiveness Of Endorphins Massage And Ice Packs To Relieve The First Stage Of Labor Pain Among The Pregnant Women in Candimulyo Health Center, Indonesia. Proceeding 2 Nd International Conference on Applied Science and Health, 03, 109114. Retrieved from https://publications.inschool.id/index. php/icash/article/view/133

Diana, U. (2016). Gambaran Pemberian Auditory Murottal Terhadap Penurunan Rasa Nyeri Ibu Inpartu Kala I Fase Aktif Di Rumah Bersalin Mattiro Baji Kabupaten Gowa Sulawesi Selatan Tahun 2016 (Fakultas Kedokteran Dan Ilmu Kesehatan Universitas Islam Negeri Alauddin Makassar). Retrieved from http://repositori.uinalauddin.ac.id/4130/

Dinas Kesehatan Kabupaten Banyuwangi. (2017). Profil Kesehatan Banyuwangi. Profil Kesehatan Banyuwangi, 7.

Febriani, T. (2019). Analisis Praktik Klinik
Keperawatan Pada Pasien Acute Coronary Syndrome (Acs) Dengan Intervensi Inovasi Thai Massage Kombinasi Terapi Murottal Al-Qur'an Surah Ar-Rahman Terhadap Penurunan Skala Nyeri Dada Di Ruang Intensive Cardiac Care Unit (ICCU) RSUD Abdul Wahab Sjahranie (Vol. 53). https://doi.org/10.1017/CBO9781107 415324.004

Hindriati, T., Novilda, A., Bidan, M., \& Rafida, N. (2019). Pengaruh Effleurage Massage terhadap Nyeri Persalinan Kala I Fase Aktif di Praktik Mandiri Bidan Nuriman Rafida dan Praktik Mandiri Bidan Latifah Kota Jambi Tahun 2019. 19(3), 590-601. https://doi.org/10.33087/jiubj.v19i3.7 64

Irawati, A. (2018). Pengaruh Endorphin Massase Terhadap Rasa Nyaman Selama Proses Persalinan Di Puskesmas Mahalona Kabupaten Luwu Timur. 53(9), 1-7. https://doi.org/10.1017/CBO9781107 415324.004

Khasanah, N. A., \& Sulistyawati, W. (2020). Pengaruh Endorphin Massage Terhadap Intensitas Nyeri Pada Ibu Bersalin. Journal for Quality in Women's Health, 3(1), 15-21. https://doi.org/10.30994/jqwh.v3i1.43

Manuaba. (2012). Ilmu Kebidanan, Penyakit Kandungan Dan Keluarga Berencana Untuk Pendidikan Bidan. Jakarta: EGC.

Melda, B., \& Mufidah, A. (2018). Decrease of Anxiety and Pain Delivery of Mother Inpartu Primipara on First Phase Active by Giving of Murottal Al Quran Arrahman in 
PROFESIONAL HEALTH JOURNAL

Volume2, No. 2, Juni 2021 (Hal. 64-74)

https://www.ojsstikesbanyuwangi.com/index.php/PHJ

Midwifery Private Clinic Endang Sumaningdyah City of Kediri. The 2nd International Conferences, 742750 .

Mulyani, A. (2018). Pengaruh Aplikasi Kontraksi Nyaman Terhadap Perubahan Intensitas Nyeri Pada Persalinan Kala 1 Fase Aktif Di Wilayah Kerja Puskesmas Cibeureum Kota Tasikmalaya Tahun 2017. Jurnal Kesehatan Bakti Tunas Husada: Jurnal Ilmu-Ilmu Keperawatan, Analis Kesehatan Dan Farmasi, $\quad$ 17(2), 202. https://doi.org/10.36465/jkbth.v17i2.2 23

Prawitasari, E. (2018). Pengaruh Kompres Dingin terhadap Perubahan Nyeri Persalinan Kala 1 Fase Laten di BPM Ny. Nur Laila, SST Kecamatan Rogojampi Kabupaten Banyuwangi Tahun 2018. STIKES Banyuwangi.

RISKESDAS. (2018). Riset Kesehatan Dasar. Retrieved from https://www.google.com/search?client $=$ firefox $-b-d \& q=$ riskesdas $+2018 \#$

Rochmawati, N. P. (2018). Pengaruh Murottal Qur'an Terhadap Nyeri Post Operasi (Di Paviliun Asoka RSUD Kab. Jombang) (Vol. 105). https://doi.org/10.1017/CBO9781107 415324.004

Salmiyati, S., \& Amizuar, Y. F. (2020). The effectiveness of al-qur'an healing with audio-visual methods in reducing pain in the active phase of the first stage of labor. International Journal of Health Science and Technology, 1(3), 7-14. https://doi.org/10.31101/ijhst.v1i3.12 02

Tanjung, W. W., \& Antoni, A. (2019).
Efektifitas Endorphin Massage Terhadap Intensitas Nyeri Persalinan Kala I pada Ibu Bersalin. Jurnal Kesehtatan Ilmiah Indonesia (Indonesian Health Scientific Journal), 4(2), 48-53.

Trianingsih, I. (2019). Pengaruh Murotal Al Qur'an Dan Dzikir Terhadap Intensitas Nyeri Kala I Persalinan. 15(1), 26-30.

W Leny, R. C., \& Machfudloh. (2017). Terapi Endorphin Massage Untuk Menurunkan Intensitas Nyeri Endorphin Massage Therapy To Reduce The Intensity Of Pain During The Active Phase Of Labor. Jurnal SMART Kebidanan STIKES Karya Husada Semarang, 4(2), 1-8.

Wahyuni, T. S., Purba, J., \& Batubara, A. (2019). Perbandingan Efektivitas Terapi Panas Dan Endorphin Massage Terhadap Intensitas Nyeri Kala I Fase Aktif Persalinan Normal Ibu Primipara. Publikasi Kebidanan, 10(1), 99-110. Retrieved from https://www.google.com/url?sa=t\&rct $=\mathrm{j} \& \mathrm{q}=\&$ esrc $=\mathrm{s} \&$ source $=$ web $\& \mathrm{~cd}=2 \&$ $\mathrm{cad}=\mathrm{rja} \&$ uact $=8 \& \mathrm{ved}=2 \mathrm{ahUKEwiNz}$ 6P5_oDmAhVj4jgGHcHiCPMQFjA BegQIBhAC\&url=http $\% 3 \mathrm{~A} \% 2 \mathrm{~F} \% 2 \mathrm{~F}$ ojs.akbidylpp.ac.id\%2Findex.php $\% 2 \mathrm{~F}$ Prada\%2Farticle\%2Fview\%2F498\%2 F48484899\&usg=AOvVaw0WSIO8P vfvfTdieXL89yPN

Yana, R., Utami, S., \& Safri. (2015). Efektivitas Terapi Murottal Al-Qur'an Terhadap Intensitas Nyeri Persalinan Kala I Fase Aktif. Jom, 2(2), 13721381. 